\title{
António Vieira: A Jesuit Missionary to the Portuguese Jews of Amsterdam
}

\author{
Adma Muhana \\ University of São Paulo, Department of Classical and Vernacular Letters, \\ São Paulo, Brazil \\ adma@usp.br
}

\begin{abstract}
Between the years 1646 and 1648, António Vieira maintained close contact with the Portuguese-Jewish community of Amsterdam, in particular with Menasseh ben Israel, a rabbi of Portuguese-converso origin. Under interrogation by the Inquisition, Vieira characterized this period of his life as the one in which he began to elaborate his messianic thesis of the so-called Fifth Empire. Unlike ben Israel, however, Vieira maintained that the Fifth Empire would arrive when the Jews recognized Christ as the messiah. Moreover, commanded by a Portuguese emperor-king, these Fifth Empire Christianized Jews would have their own political state, king, and cultural ceremonies. Always a missionary, Vieira argued that Jews would convert to the Catholic faith without the use of force as long as their idiosyncratic expectations were accepted, much like the Asian peoples and Indians of the New World, who, despite having been converted by the Jesuits, maintained some of their customs, beliefs, and institutions.
\end{abstract}

\section{Keywords}

António Vieira - "men of the nation" - New Christians - Menasseh ben Israel - Jews mission - millenarianism - rhetoric

\section{Introduction}

Previous research has examined the contact maintained by António Vieira (1608-97) with members of the Portuguese Jewish communities, not only in Amsterdam, but also in The Hague, Rouen, and Hamburg-in particular, 
his meeting with the Portuguese rabbi Menasseh ben Israel, né Manuel Dias Soeiro (1604-57). ${ }^{1}$ Despite this extensive scholarship, the theological aspects of the dialogue between Vieira and ben Israel, as recorded in the former's letter, Esperanças de Portugal (Hopes of Portugal), and in the latter's book, Esperança de Israel, have received little scholarly attention. The work of António José Saraiva is an exception in this regard. Saraiva has identified how Vieira incorporated into his writings much of what was being discussed in Jewish and Christian circles in the Netherlands in the mid-seventeenth century, in particular the idea of the Fifth Empire. Yet, Vieira included Jewish texts, concepts, and metaphors in his writings not because he accepted them, but rather in order to use them as constitutive elements of a latitudinal missionary Catholicism. In a parallel manner, in his concessions to Christianity, ben Israel presented a broad, apologetic, and even quasi-proselytical form of Judaism.

In this article, I demonstrate how Vieira's defense of Judaism and the favoring of Jews, for which he was tried by the Inquisition, first and foremost consisted of a defense of the Portuguese merchants exiled from the Iberian Peninsula - whether or not they had Jewish origins and whether or not they adopted Judaism as a religion. I further suggest that Vieira's acceptance of particular Jewish principles was related to his missionary purposes towards these communities, following the approaches of his fellow Jesuits vis-à-vis indigenous peoples of Brazil or Confucians in China.

Finally, it is worth mentioning that in Amsterdam, as well as in other places beyond the Pyrenees, Jewish-Portuguese communities were established by "New Jews." ${ }^{2}$ The reference is to Portuguese individuals, predominantly descendants of New Christians, who were uprooted from the Iberian

1 António José saraiva, “António Vieira, Menasseh ben-Israel e o Quinto Império," in História e utopia: Estudos sobre Vieira (Lisbon: ICALP, 1992), 75-107; José van den Besselaar, "Antonio Vieira e a Holanda," Revista da Faculdade de Letras 24 (1971): 5-35; Christofer Lund, "António Vieira e Menasseh ben Israel, uma aproximação de dois hermeneutas," Veredas 2 (1999): 79-83; Natalia Muchnik, "António Vieira y la diáspora sefardí en el siglo XVII," in António Vieira, Roma e o universalismo das Monarquias portuguesa e espanhola, ed. Pedro Cardim and Gaetano Sabatini (Lisbon: Universidade Nova de Lisboa, 2011), 97-119; Florence Lévi, "La prophétie et le pouvoir politico-religieux au Xviı siècle au Portugal et en Hollande: Vieira et Menasseh ben-Israel," in La Prophétie comme arme de guerre des pouvoirs (XVe-XVIIe siècles), ed. Agustin Redondo (Paris: Presses de la Sorbonne Nouvelle, 2000), 433-45.

2 An expression felicitously coined by Yosef Kaplan to designate Portuguese descendants of New Christians "converted" to Judaism in the Netherlands and in other European Jewish communities, many of them without knowing Jewish religious principles beforehand, except possibly through books that challenged them. See Yosef Kaplan, Les Nouveaux Juifs d'Amsterdam: Essai sur l'histoire sociale et intellectuelle du judaisme séfarade au xviie siècle (Paris: Chandeigne, 1999). 
Peninsula after escaping the Inquisition and became Jewish in their new places of residence, although they were unaware of the most basic principles of Judaism. Most of these individuals emigrated to Christian countries, such as the Protestant Netherlands or German-speaking lands, or even to Catholic France and the Italian peninsula, where Judaism was barely tolerated. Various of these "Portuguese nations," as in the case of Bordeaux, Saint Jean de Luz, Labastide Clairence, Nantes, and Rouen and other smaller communities in France, eventually shed their Jewish identity and became Christian, even after rabbis and Jewish institutions were allowed entry. In England, many of these groups adopted a kind of secular or "modern" form of Judaism, as Yosef Kaplan has masterfully shown. ${ }^{3}$ This largely explains why, on more than one occasion, Vieira maintained that he could bring these "men of the nation" back to the kingdom and to their original religion (i.e. Catholicism).

When fifteen-year-old Vieira entered the Society of Jesus in the city of Salvador da Bahia de Todos os Santos in Brazil, the Society was experiencing a golden era of missionary expansion. In the 1620 s, in addition to the schools and residences of the Society found throughout Europe, there were houses in Goa, Ternate, Malacca, and Cochin in Portuguese India; in Macau, China; in Yamaguchi, Japan; in Luanda, Angola, and Alexandria in Egypt; in Florida, Mexico, and Lima in Spanish America; and in Olinda, Salvador, Rio de Janeiro, São Vicente, São Luis, and Belém do Pará in Brazil, among many others. At that time, the Society had more than fifteen thousand members spread over 372 schools in thirty-two provinces. ${ }^{4}$ With his oratory gift and missionary fervor, Vieira asked to go into the Sertão, the inland, arid region in northeastern Brazil, to convert indigenous people and make them subjects of the crown. These native people were dispersed throughout the Brazilian territory and posed a threat to the few insular enclaves of the Portuguese population. Vieira's superiors, however, put off this missionary activity, sending him instead to teach at the Society's school in Olinda, where he honed his knowledge of languages and rhetoric.

During this time, following the death of King Sebastian (1554-78) in a war against the Muslims in Morocco, the Kingdom of Portugal, along with its

3 Yosef Kaplan, "La diáspora judeo-española-portuguesa en el siglo XVII: Tradición, cambio y modernización," Manuscrits: Revista d'historia moderna 10 (1992): 77-89.

4 See, among others: John W. O'Malley, The First Jesuits (Cambridge, MA: Harvard University Press, 1993); Jean Lacouture, Jésuites: Une multibiographie; Les Conquérants (Paris: Seuil, 1991). Bruno Feitler, “'A sinagoga desenganada': Um tratado antijudaico no Brasil do começo do século XVIII," Revista de história 148 (2003): 103-24; Thomas Cohen, "A admissão de minorias raciais e étnicas na Companhia de Jesus, 1540-1773," in Estudos sobre Vieira, ed. João Adolfo Hansen et al. (São Paulo: Ateliê, 2011), 271-92. 
territories, was annexed in 158 o by King Phillip II of Spain (1527-98), who was thereby rendered Philip I of Portugal. The Jesuits played a major role in supporting this dynastical union, attracting to Iberian Catholicism the various populations of the two empires, along with their rich and variegated languages, religions, and customs. Of course, in the seventeenth century, the Iberian empire was at its peak. Along with goods, merchant ships carried missionaries, soldiers, administration officials, and Jesuit letters between the various hubs of the Iberian world. In the absence of priests, these letters established communication between the empire's schools and churches in both the West and the East Indies and encouraged them to adopt homogeneous religious and educational practices. Much has been written about the enthusiasm of priests, students, and novices on both sides of the ocean upon receiving these annual letters, which recounted successful conversions or the difficulties that the missionaries had undergone in these conquests. One example is the letter sent by Luís Fróis (1532-97) from the school in Goa to Coimbra in 1552:

The letters that came from Portugal, being from this College and from Brazil, in the year 52 , overjoyed us, and aroused much fervor. On the night they arrived, they were read to the sound of the bell until one hour past midnight and in the refectory for the next ten days. And then, once a summary of them had been copied, they were sent to China, Japan, the Malacca and Moluccas, and all those places where our Fathers tread. ${ }^{5}$

The by-then novice Vieira was assigned to write the carta annua from the province of Brazil in 1626, recounting the invasion of Bahia by the Dutch Protestants. Vieira's fame as an orator and writer redoubled, leading to his dispatch to Lisbon to greet the new king upon the dynastical "restoration" of the Portuguese throne by King John IV (1604-56) in 1640. The dynastical restoration was challenged by Spain's refusal to recognize it and by the attacks launched by the Netherlands, England, and France on Portugal's colonial possessions in Brazil, Africa, and India. In addition, until 1668, no European nation, including the Holy See, was eager to risk provoking King Philip IV's Spain on account of the "restored" and fragile Portugal.

The first known writing by Vieira on New Christians and "men of the nation" dates from the period in which he became advisor to King John IV. In 1643, shortly after his arrival in Lisbon, he wrote a political treatise in which he

5 See Serafim Leite, "Expansão das cartas do Brasil pela Europa e o Extremo Oriente," in Cartas dos primeiros jesuitas do Brasil (São Paulo: Comissão do IV Centenário da Cidade de São Paulo, 1954), 1:54. Cf. João Adolfo Hansen, "O nu e a luz: Cartas jesuíticas do Brasil," Revista do Instituto de Estudos Brasileiros 38 (1995): 87-119, here 108. 
opined that the survival of his fragile kingdom hinged on the war between powerful Castile and France. ${ }^{6}$ The Portuguese kingdom was then in a miserable state, with few ploughed lands and even less cash. Moreover, the Dutch had encroached upon the empire by conquering a portion of its colonial possessions. Vieira proposed that the king call to Portugal the New Christians who were in "Holland and Castile, Flanders, France, Italy, Germany, Venice, and the West Indies." 7

The first suggestion that Vieira sets forth in his appeal is above all economic and political. Because merchants bring with them the goods from the kingdoms in which they live, Vieira proposes withdrawing prosperous Portuguese merchants from kingdoms inimical to Portugal, thus hurting those kingdoms financially and strengthening the Portuguese resistance. These "men of the nation," Vieira argues, are Christians against whom the only possible objection is the suspicion they are not truly baptized, that is, that they are not inwardly Christian. Vieira's secondary consideration is religious. The heretical Dutch, by conquering territories that had once been Catholic, had spread Protestantism in Brazil and India. Bringing the men of the nation back to Portugal, Vieira claims, would curtail the dissemination of that Protestant "heretical error," while luring ex-conversos and their children back to Catholicism. Thus, Vieira concludes, the return of the men of the nation to the kingdom would align fully with the chief goals of Catholicism.

In 1646, King John IV dispatched Vieira on a diplomatic mission to France and the Netherlands. In France, he was to negotiate a marriage alliance that would protect Portugal from Spain. This negotiation failed. His purpose in the Netherlands, specifically in The Hague and Amsterdam, was to negotiate a possible repurchase of Pernambuco and Angola that the Dutch had taken over from Portugal. On that trip, Vieira also stopped in Rouen, where he held

6 In Portugal and in the Sephardic diaspora, practicing Jews and New Christians of Jewish-Iberian origin were called homens da nação [men of the nation]. On this slippery concept, see Miriam Bodian, "Men of the Nation': The Shaping of Converso Identity in Early Modern Europe," Past \& Present 143 (1994): 48-76.

7 António Vieira, Obras escolhidas, ed. António Sergio and Hernâni Cidade, 15 vols. (Lisbon: Livraria Sá da Costa, 1951), 4:12. Here, the text is presented as a "proposal made to King John IV, in which he is presented with the miserable state of the kingdom and the necessity of permitting entry to Jewish merchants who traveled through various parts of Europe." This is how it has been read from the nineteenth century into the present. However, in all of the various copies of the now-disappeared original, the words "Jewish merchants" do not appear in the title. In the oldest copy, at the Biblioteca Nacional de Portugal, it is entitled merely "Political Speech by Father Antonio Vieira" and, in a seventeenth-century collection, "Political Opinion That Was Given to King John on the Increase of the Kingdom," concluding that "New Christians are recorded in it by Fath. Antonio Vieyra [...] the year 1644" (José Pedro Paiva, Padre Antonio Vieira, 1608-1697: Bibliografia [Lisbon: Biblioteca Nacional, 1999], 141). 
gatherings of members of the Portuguese nation, whom he addressed admiringly, in a letter, as "the businessmen of Rouen." ${ }^{\text {It }}$ is worth recalling that a significant part of the Portuguese nation of Rouen had already chosen to return to Portugal on the occasion of the General Pardon of 1605. Even if the Holy Office was fully active, Vieira assumed that with the cessation of religious prosecution, these men of the nation would make every effort to return to Portugal's "lands of idolatry," as the Iberian territories were called by the Jewish authorities of Amsterdam.

No less significantly, these negotiations also concerned extracting large sums of money from the Portuguese businessmen-not only those living in Rouen as Catholics, but, three months later, those who lived in Amsterdam as Jews. In exchange for the promise of treatment equal to that enjoyed by the Old Christians, tax exemption, and a reform of the Inquisition's proceedings, these businessmen would help fund King John IV's policies in the kingdom and in the colonies. The agreements were negotiated through a series of arguments and refutations in a "political and Catholic" document that Vieira wrote the same year, which was published under the title "Proposal made to His Most Serene Highness John IV in favor of the men of the nation, on the change of styles of the Holy Office and the revenues of treasury, $1646 .{ }^{\prime 9}$ Writing with great eloquence, Vieira asserted that the men of the nation had been forcibly driven out of Portugal:

Many were true Christians, but either because of necessity or bad education [doutrina] and example, they sell and lose their Faith for the great sorrow and commiseration of the Catholics of those lands, who recognize that those poor men have been won over, more by the strength of temptation and circumstances than by the lack of knowledge or desire to return back; because it is certain that some of them resist six months and others for a year or two, and almost all of them vacillate between both beliefs, until finally they give up and become circumcised. ${ }^{10}$

Vieira thus proposed to the king that the denunciations against New Christians should be "open and published" so as to allow for reasonable self-defense. He

8 Dated April 2oth, 1646 , and always published with the purported title "To the Jews of Rouen." However, in the only manuscript copy from the seventeenth century, held at the National Library of Portugal, the title appears as cited here.

9 In one of the oldest manuscripts, the document is entitled: "Political and Catholic Proposal that was made to King John the 4 th in favor of the People of the Hebrew Nation and the kingdom of Portugal" (Paiva, Padre Antonio Vieira, 144).

Vieira, Obras escolhidas, 4:30-31. 
also urged that in the case of trial, the money used by the New Christians to conduct their trade activities should not be confiscated by the Inquisition but should rather be escrowed in the king's custody until the trial's conclusion. Furthermore, Vieira argued, Old and New Christians ought to be treated equally with respect to official duties, honors, and royal favors, which should not be awarded on the basis of "blood" origin.

Vieira's second, aforementioned suggestion, which involved the king's interference in the Inquisition's methods of conducting legal proceedings and the interception of money needed to run the inquisitorial machine, was a particularly strong stimulus for the Inquisition to target the Jesuit. Additionally, his determination to reintegrate New Christians into the Kingdom of Portugal unmistakably resembles the way in which the leaders of the Reformed churches had been trying to attract them to their countries. King John IV's partial acceptance of the proposal earned him a post-mortem excommunication. Vieira's situation worsened, and two of his closest allies, the New Christians Duarte da Silva (1596-1688), a merchant banker who lent enormous sums to the king, and Manuel Fernandes Vila Real (1608-52), the king's ambassador in France, were imprisoned by the Inquisitors in 1647 and 1649 respectively.

On December 1, 1652, the day that John IV's "restoration" to the throne was commemorated, Silva and Vila Real were sentenced to an auto-da-fé in the presence of the king himself. Silva was exiled to Brazil and Vila Real was burned at the stake. Recognizing the king's inability to protect even his most faithful allies, the men of the nation abandoned him. Vieira escaped to Maranhão e Grão Para in Brazil, where he remained from 1653 to 1661, ministering to the Indians. Expelled by settlers some ten years hence, he returned to Lisbon and was tried by the Inquisition.

Vieira's trial before the Tribunal of the Inquisition of Coimbra, between 1661 and 1667 , focused on the charge that he had made propositions in favor of Judaism to the detriment of Catholicism and had defended what were properly Jewish doctrines, such as the establishment of a Fifth Empire after the Roman Empire. He was accused, among other things, of having asserted that the Inquisition made Jews of New Christians. ${ }^{11}$ Vieira was familiar with the Portuguese communities in Amsterdam and Rouen and believed that Jewish hegemony in these communities was on the wane. His remarks concerned the excesses and profiteering of the Inquisition (observing that it was efficient in appropriating the assets of the descendants of New Christians accused of

11 Denunciation by Fernão Sardinha. See Adma Muhana, ed., Os Autos do processo de Vieira na Inquisição (São Paulo: Edusp, 2008), 361. Cf. Muchnik, "Antonio Vieira y la diáspora sefardí en el siglo XVII," 107. 
observing Jewish rituals). He did not deny the import of his denunciation, only the "Jewish" meaning attributed to it. This was a plausible argument in light of the peculiar construction of the Portuguese nation, principally in Amsterdam, where many New Christians were reluctant to abandon the religion into which they had been born and fully adopt Judaism, as Vieira claimed.

\section{Catechizing the New Christians}

Accounts of the discussions between Vieira and ben Israel in Amsterdam reveal the proselytizing inclination of the two men. Both were primarily orators and rhetoricians who sought to persuade their audiences to endorse their respective religious causes. As such, their argumentation aimed not only to instruct their listeners about the truths of faith, but also — and mainly — to motivate them to act on those truths. These two figures personified the frequent polemics between Judaism and Christianity in seventeenth-century Amsterdam, and their rhetoric was praised as emulatio and laudatio in more than one manuscript of the time. One example of such a polemic is the case recounted by the archbishop of Goa, Ignacio de Santa Tereza (1682-1751), in his Crisis paradoxa, published anonymously in London in 1748. The story goes that in an Amsterdam synagogue, Vieira had convinced Menasseh that the messiah, the redeemer of human spirituality, had already appeared in the person of Jesus Christ; the rabbi, in turn, convinced the priest that the messiah had to return a second time to effect redemption on earth and reunite the dispersed ten lost tribes of Israel..$^{2}$ This reconstructed competition echoes the records of the Inquisition's trial of Vieira, where the latter states that the references to Judaism in his work are the result of

not only my seeking in Holland and France to reduce the blindness of the Jews in some particular conversations (that through their ignorance do not merit being called debates); but before some of them in Amsterdam, I convinced their Portuguese master, Manasses. And calling another Italian [master], called Morteira, I also told them that they might bring me to, or choose a day and place, where they would like to hold a debate: which they did not do because Morteira did not wish to do so. ${ }^{13}$

12 Crisis Paradoxa super tractatu insignis P. Antonii Vieyrae ... (s.l.: s.n., 1748).

13 Muhana, ed., Os Autos do processo de Vieira na Inquisição, 306. Obviously, it would not have been due to fear that the principal rabbi of the Amsterdam community would have avoided becoming involved in controversies with a Catholic priest; the prohibition against theological disputes between Jews and Christians, implicit in the laws of Amsterdam and 
In these conversations, Vieira seemingly applied the same theological and rhetorical principle of accomodatio that he employed in his activities with the indigenous peoples of the New World, as did many of his fellow Jesuit missionaries throughout the Portuguese world. ${ }^{14}$ Vieira exploited this principle to advance his Catholic missionary efforts among Jews by utilizing some Jewish concepts and notions. Jewish authors among the Portuguese nation of Amsterdam - as the laws and regulations of this community, as well as the letters, testimonies, and even witness depositions at the Inquisition, demonstrate-sought to "convert" those Portuguese who had been uprooted from the peninsula to Judaism by similar tactics. The Jewish proselytizers adapted concepts that were richly redolent of Catholic references (such as naming biblical characters as saints-Saint Esther, Saint Tobias, etc.); bestowed Jewish names upon those relatives who had died in the Iberian peninsula without converting to Judaism; decorated Jewish tombs with human and animal figures; and professed the belief that the observance of Judaism brings individual salvation.

In the Apologia, an unfinished text written between 1663 and 1664 during the Inquisition's interrogations, as proof of the proposition that the Scriptures had already prophesized the voluntary conversion of Jews to Christianity during the Fifth Empire, Vieira employs the figure of Jacob,

who after working so many years to have Rachel [as his wife], was given and received Leah in her place, provoking this exchange in the darkness of night: and finally after Jacob took Leah as his wife, he also married his much-beloved Rachel, who was the first purpose and price for which he worked. In the same manner, the Son of God came into this world where he worked so many years to marry the ancient Church [Igreja antiga] which in those times was only comprised by the Hebrew People, His Beloved People; but due to Laban's deception, who is the Devil, and by the darkness of night, which is the blindness of incredulity, Christ did not manage to obtain the betrothal he intended to obtain from the Hebrew nation, and, in their place, came the older sister that was Gentility (because

recorded in the Talmud, prohibited Jews from inviting or allowing in any Christian to their houses of prayer for the purpose of discussing or disputing religious matters.

14 On the Jesuit concept of accommodation, see Andrew Ross, A Vision Betrayed: The Jesuits in Japan and China, 1542-1742 (Edinburgh: Edinburgh University Press, 1994); Joan Pau Rubiés, "The Concept of Cultural Dialogue and the Jesuit Method of Accommodation: between Idolatry and Civilization," Archivium historicum Societatis Iesu 74, no. 147 (2005): 237-80; Andrés Prieto, "The Perils of Accommodation: Jesuit Missionary Strategies in the Early Modern World," Journal of Jesuit Studies 4, no. 3 (2017): 395-414, https://brill.com/view/ journals/jjs/4/3/article-p395_395.xml (accessed October 22, 2020). 
Gentiles first came to the world before Jews) and after Christ received in His house all the Gentile nations, Leah, who was less shapely but more fertile, then he also received with much more happiness and satisfaction, his Beloved, Rachel, i.e., the Jewish People, who were the first price for His works, and the first care and sleeplessness of His love. ${ }^{15}$

Underlined in the original, this is one of more than one hundred of Vieira's propositions that were censored by the Holy Office and which became the subject of Inquisitorial Examinations 25 and 26 in May and June of 1667. The inquisitors questioned the preeminence he accorded to the Jewish people at the expense of the Gentiles, to which Vieira responded with a distinguo: the Jewish people are not synonymous with Judaism in the same manner that Gentiles are not synonymous with Christianity:

When asked as was just been said, whether Leah was a figure of the Synagogue, or the Church of the Jews, and Rachel that of the Gentiles or Christians; what was the basis for the deposer to write or say this [...], that Leah, being less shapely but more fertile was a figure of the Church of the Gentiles, whom the Son of God took as a bride, coming into the World, receiving in his house the Gentile nations, and Rachel was the figure of the people and Jewish nation, whom Christ also intended to marry, but did not manage to do, as still it has to be achieved, through the general conversion of the Jews. He said that, the declarant, in a sheet appended hereto (which had been read to him now at this session), in no way made a comparison nor intended to make a comparison between the Church of the new law and the Church of the old law, but rather between two peoples, the Gentile and the Jewish, as can be clearly seen in the intention of that paper, which was to show, that the first aim of Christ was to unite unto himself and to the Faith of the law of Grace, the Jewish people, and afterwards, the Gentiles; but due to the blindness and complete obstinacy of the Jews, the destinies were exchanged, and thus the Gentile people came in first place, whereas the Jewish people came second; and that in this sense, it seemed to him, that the qualities of Rachel vis-à-vis of Leah, which fully applied to the said people and Jewish nation, whereas the [qualities] of Leah [corresponded] to the Gentile people. ${ }^{16}$ 
Responding to this distinction, Inquisitor Alexandre da Silva (1614-82) questioned Vieira about identifying the people and the church in relation to Gentiles and Jews. In his answer, Vieira claimed that his reference to Judaism did not include the Jewish people, but rather biblical Judaism, and in no way validated the contemporary Jewish religion. As a people, Jews were chosen by God in the Old Testament, but they had been replaced by the Gentiles in the New Testament and their election had been suspended. In religious terms, Vieira concluded, Judaism had been forever supplanted by the advent of Christianity.

The distinction made by Vieira between the Jewish people and the Jewish religion was probably based on his knowledge of the migrations of the descendants of the New Christians from the Iberian Peninsula, the Jewish proselytizing efforts targeted towards them, and their "conversion" as "New Jews." His personal contact with men of the nation reinforced his conviction that those who were affiliated with Judaism were generally people who, rather than seeking to embrace another religion, had fled the Iberian Peninsula to be able to live freely and safely. Yet, in the proposal that he sent to King John IV in 1646, Vieira emphasized the personal wealth of the New Christians, just like the goods and wealth coming from the New World and other colonies, because of the salvific role it was to play in the spread of Catholicism, for which all material things were created and for whose sake they needed to be recovered for Portugal.

As for the Portuguese nation in Amsterdam, which was proud of its Jewish and Iberian roots, it oscillated for years before finally defining itself as Jewish. In the mid-seventeenth century, when Vieira first came to know this community, its members still wanted to be part of the Portuguese realm, as descendants of Catholics, proud of their Jewish and Christian forefathers, who deliberately adopted the Jewish religion. Even so, the nation clung to certain practices that distinguished it from Jewish communities of other origins, such as defining itself by its relationship to the Iberian homeland rather than in religious terms, and separating religion from business, distancing the dictates of Jewish law from economic life. It also diverged from Jewish communities of other origins in the high number of "dissidents" who returned to Catholicism, only to then convert to Protestantism or Deism. ${ }^{17}$

Ultimately, Jewish and Christian theologians and orators, in attracting these men and women of the Portuguese nation to their respective folds, grounded themselves on common, shared principles. The particular religious and ethnic

17 See Matt Goldish, "The Amsterdam Portuguese Rabbinate in the Seventeenth Century: A Unique Institution Viewed from Within and Without," in Dutch Jewish History 2: Proceedings of the Symposium on the History of the Jews in the Netherlands, ed. Jozeph Michman (Jerusalem: The Hebrew University of Jerusalem, Institute for Research on Dutch Jewry, 1989), 9-19. 
make-up of the Portuguese New Jews helped thinkers like Vieira and ben Israel, despite the differences between their beliefs, to elaborate a conciliation of certain aspects of the Old and New Testaments - of which those descendants of Portuguese Jews were living proof. That is to say, the existence of communities of Portuguese New Jews was demonstrative of the dawn of the messiah's kingdom or Fifth Empire, where a political state for the Jewish people would be admissible into the concert of Christian nations.

\section{The Salvation of Men in the Fifth Empire}

The first charge against Vieira during his Inquisition trial in Coimbra was related to his "Esperanças de Portugal" (Hopes of Portugal), a letter he had sent in 1659 to the regent queen of Portugal and widow of King John IV, Luisa de Gusmão (1613-66), through her confessor, the Jesuit André Fernandes (160760 ). By employing a syllogism, the letter endorsed a "non-Sebastianist" interpretation of the Trovas (Verses) of the Portuguese cobbler-prophet Gonçalo Anes Bandarra (1500-56), proposing that King John IV, who had died three years earlier, would come back again to life as the "hidden king." Nowhere does the text mention "Fifth Empire," a term that does, however, appear on the front cover of the manuscript: "Hopes of Portugal, Fifth Empire of the World, the First and Second Life of King John the Fourth." Vieira's conception of this Fifth Empire is the focus of the tenth and seventeenth examinations of his Inquisitorial trial.

In addition to the letter, the trial introduced a denunciation by Father Jorge de Carvalho (1606-77) concerning books that Vieira apparently claimed he was intending to write, which gave rise to the second inquisitorial examination. During the trial, Vieira admitted that he was thinking about writing two books: Conselheiro secreto (Secret advisor) and Clavis prophetarum (Key of prophets). He stated that the first book reflected his evangelizing activities as a missionary of the Society of Jesus by attempting to convert Jews to the Catholic faith:

[Vieira] was intending to write in Portuguese another book entitled Secret Advisor, the main subject of which would have to be to provide arguments to convince any Portuguese Jew to convert to the faith of Christ Our Lord based on the lessons stated in the book. In it, I decided to propose and set forth all the fundamentals for doing so and impugn those which might lead the Jews to follow the belief in the law of Moses. ${ }^{18}$ 
As for the second book, Clavis prophetarum, he asserted that, in 1646 or 1647 , he was writing a book

hat [he] intended to entitle, Clavis prophetarum, the main subject and the topic of which is to show, by using some propositions, with references to the Scriptures, and Saints, that in God's Church, there must be a new, different state than the one there has been until now, [and] that in all the nations of the World, there must be belief in Christ Our Lord, and the embracing of our Holy Catholic Faith; and that the grace of God must be so copious, that everyone or almost every one of those who are alive must be saved, in order to fulfil the number of those who are predestined. ${ }^{19}$

Taking into consideration these circumstances, we can infer that the time of writing of that book coincided with Vieira's contact with Amsterdam's Jewish Portuguese nation, suggesting a dialogue between his exegesis and that of the rabbis of Iberian origin living in The Netherlands, such as ben Israel (but perhaps also Isaac Aboab da Fonseca [1605-93] and Moses Raphael d'Aguilar [c.1611-79], among others). Moreover, Vieira explained that in the Clavis prophetarum, he further developed the idea of the Christian Fifth Empire that had first appeared in his letter "Hopes for Portugal." This last terrestrial empire, promised in both the Old and New Testaments, would be a new and long-lasting peaceful state of the world which would precede the universal resurrection of the dead at the end of days.

In the writings that he composed during the trial, Vieira based himself on propositions originating with both Jewish and Christian rabbis and theologians, namely disassociating the Fifth Empire from the messiah's eternal reign while integrating the Jews (including their Portuguese offspring) into this upcoming Christian Empire.

This notion of the Fifth Empire is found in the Book of Daniel, which holds a special place in the Jewish canon, as it promised an earthly empire to the Jews in the time of the messiah. This idea of empire is based on the book's account of Nebuchadnezzar's dream, understood as prophetic, about a statue comprised of four metals that is overturned by a stone. Attributed to the second century вСЕ, the Book of Daniel presents the dream's statue as an allegory of the succession of four empires ruling the earth so as to signify that a fifth and final earthly empire, engraved on the stone, would be that of the Jewish kingdom of the messiah. As it was the sole book promising a temporal kingdom of

19 Muhana, ed., Os Autos do processo de Vieira na Inquisição, 77. 
the messiah during the end of times and the only one announcing the resurrection of the dead, some "New Jews" rejected it as a fake-as did the authors Uriel da Costa (c.1585-1640) in his Exame das tradições fariseias (Examination of Pharisaic traditions), written in $1624,{ }^{20}$ and Baruch Spinoza (1632-77) in his Tractatus theologico-politicus, written in $1670 .{ }^{21}$ In response to all those who did not recognize the Book of Daniel as an authentic text, ben Israel published in 1636 his three-volume De la resurrección de los muertos or De resurrectione mortuorum (On the resurrection of the dead) in Latin and Spanish; its main audience was the "New Jews" who knew the latter language. Far from exhausting the Portuguese rabbi's work on the topic, the book was followed in 1647 by the publication, in his own printing house, of a commentary in Hebrew on the Book of Daniel written by Isaac Abravanel (1437-1508) as well as the publication in 1651, also in Hebrew, of the four-volume Nishmat hayyim (On the immortality of the soul). Finally, in 1655, he published in Spanish his Piedra gloriosa o de la estatua de Nebuchadnesar (The glorious stone or the statue of Nebuchadnezzar), where he expounds what is clearly a political interpretation of the statue allegory, concluding that

because the four Monarchies were temporal, from various princes, different nations and diverse lands, Babylonians, Persians, Greeks and Romans, it follows that also the fifth shall be of various nations and different lands, and, consequently, of the people of Israel, who possessed Judea, by divine gift; and likewise, the messiah (who is the stone) shall destroy with temporal and earthly dominion all the other Monarchies. And in the very manner that the Persians destroyed the Babylonians, and conquered

"This book of Daniel is rejected by the Jews called Sadducees and this fact alone should suffice to deprive a book of its credibility. (As we have said, very little faith can be placed in the unconfirmed testimonies of the Pharisees, seeing how these men made it their business - or their madness - to change word, modify, twist, and misinterpret Scripture in order to confirm the confused figments of their imagination). In his case, the book's content reveals it to be nothing but a product of a Pharisaic ideology, contrary to that of the Law. It masquerades as prophecy, the better tool to fool the people by lending authority to its author's false teaching" (Uriel da Costa, Examination of Pharisaic Traditions, Exame das tradições farisaicas: Facsimile of the Unique Copy in the Royal Library of Copenhagen, Supplemented by Semuel Da Silva's Treatise on the Immortality of the Soul, Tratado da immortalidade da alma, ed. Herman P. Salomon and Isaac S. D. Sassoon [Leiden: Brill, 1993], 339).

21 "The reason driving me to assert it was the Pharisees alone who selected the books of the Old Testament, placing them in the canon of sacred books, is that Daniel 12.2 affirms the resurrection of the dead which the Sadducees denied" (Benedictus de Spinoza, Theological-Political Treatise, ed. Jonathan Israel and Michael Silverthorne [Cambridge: Cambridge University Press, 2007], 153-54). 
their lands; the Greeks, those of the Persians; the Romans, those of the Greeks, thus the messiah and the people of Israel, ending with this latter (that into its own [monarchy] have incorporated the others) shall be the lords of the world with temporal, terrestrial and eternal dominion, according to this infallible interpretation of Daniel. ${ }^{22}$

Christian millenarian writings also featured Nebuchadnezzar's dream about the statue, interpreted as the kingdom of Christ in his second coming. The seventeenth-century authors Paul Felgenhauer (1593-1677), Petrus Serrarius (16oo-69), and Isaac de la Peyrère (1596-1676), among others, held that a day of universal peace would come in which believers in the Old and New Testament would be reunited. In the case of the militant millenarianism of Vieira, this empire would come about when Jews, after most of the Gentile nations, recognized Christ's divinity, hence the fundamental importance of the missionary activities of both Gentiles and Jews.

According to Jerome's (c.347-420) commentary—a significant influence on later Christian interpretations of the Book of Daniel—human history was moving toward the Creator, its final cause. Thus, a time at the end of history may be supposed when all religions would heed those preaching the Gospel and submit to Christianity. For Vieira, such a universal conversion would include both the Gentiles and the Jews, adding the secluded Ten Lost Tribes of Israel, who would be found somewhere in a fifth part of the world not yet discovered by the Portuguese. This final epoch would culminate with the devastation of Muslims upon the foundation of a Christian Fifth Empire, temporal yet spiritual, under the aegis of a Portuguese king. ${ }^{23}$ Such an empire would commence at the end of the "Roman Empire," thus bringing to a close the thousand-year cycle of five earthly empires, at the end of which the Antichrist would reign until the final triumph of Christ and the people of God. At that time, the dead would be resurrected, and the final judgment of every person would take place. ${ }^{24}$

22 Menasseh ben Israel, 'Even yeqarah: Piedra gloriosa o de la estatua de Nebuchadnesar (Amsterdam: n.p., 5415 [1655]), 26-27.

23 Alterity in relation to Muslims is a central element for the assumption of proximity between Jews and Christians in the seventeenth century, as Claude B. Stuczynski has shown in his “What Does 'Judeo-Christianity' Mean in Late-Medieval and Early Modern Iberia?," Cadernos de estudos sefarditas 20 (2019): 11-33.

24 Since the seminal study of Raymond Cantel, Prophétisme et messianisme dans l'oeuvre d'Antonio Vieira (Paris: Ediciones Hispano-Americanas, 1960), important studies on Vieira's millenarianism have been published: Alain Milhou, "La chauve-souris, le nouveau David et le roi caché (trois images de l'empereur des derniers temps dans le monde ibérique: XIIIexvire s.," Mélanges de la Casa de Velásquez 18 (1982): 61-78; Thomas Cohen, "Millenarian Themes in the Writing of Antonio Vieira," Luso-Brazilian Review 28 (1991): 23-46; José van 
As evidenced in the História do futuro and the Apologia, Vieira hardly hesitated in his determination of the timing of the resurrection of the dead. He even presented two general resurrections as exegetical hypotheses: one at the time of the Fifth Empire, and another, later one at the time of the final judgment. ${ }^{25}$ The latter possibility, although dismissed by Menasseh ben Israel, had already been proposed by Maimonides (1138-1204) — or Rabbi Moses of Egypt, as Vieira called him, in line with the Christian custom ${ }^{26}$ — who was widely read both by Jews and Christian Hebraists in the seventeenth century. ${ }^{27}$

In any event, in both Christian and Jewish circles, the Book of Daniel was deemed as divinely inspired writing. Scholars, whatever their background, shared the belief that, pursuant to the book's prophesy, an era of secular happiness would flourish until the end of history, when the just, both living and dead, would be rewarded with eternal life and resurrection in the world to come after the Final Judgment. Most of mankind would be saved in this world, thus realizing the rabbinic dictum that "all Israel will be saved" and invalidating the exclusivity propounded by the Inquisitors. In fact, Vieira used the Inquisition's investigations against him to write texts that obliquely dialogue with those of Rabbi ben Israel, responding to them both politically and rhetorically.

Vieira's emphasis on points common to Christianity and Judaism goes beyond mere theological abstraction. In a very practical way, this emphasis

den Besselaar, Antônio Vieira: Profecia e polêmica (Rio de Janeiro: UERJ, 2002); Silvano Peloso, Antonio Vieira e l'impero universale: La Clavis Prophetarum e i documenti inquisitoriali (Viterbo: Sette Città, 2005); Maria Ana Travassos Valdez, Historical Interpretations of the 'Fifth Empire': The Dynamics of Periodization from Daniel to António Vieira, S.J. (Leiden: Brill, 2011); Luis Filipe Silverio Lima and Ana Paula Torres Megiani, "An Introduction to the Messianisms and Millenarianisms of Early Modern Iberian America, Spain, and Portugal," in Visions, Prophecies and Divinations: Early Modern Messianism and Millenarianism in Iberian America, Spain and Portugal, ed. Luis Filipe Silverio Lima and Ana Paula Torres Megiani (Leiden: Brill, 2016), 1-41.

25 E.g. "It could be another resurrection [of the dead] (and a resurrection of many), before the universal resurrection, without going against the truth of those texts which are invoked to claim the opposite, particularly those of the Old Testament, which were written many hundreds of years ago before these Saints were resurrected [after Matthew 27:52-53: "and the graves were opened; and many bodies of the saints who had fallen asleep were raised; and coming out of the graves after His resurrection, they went into the holy city and appeared to many"]" (Vieira, Apologia, 273).

26 Cf. Giuseppe Laras, Immortalità e resurrezione nel pensiero ebraico medievale (Milan: Universitá degli Studi di Milano, 2001), 133.

27 See Aaron L. Katchen, Christian Hebraists and Dutch Rabbis: Seventeenth Century Apologetics and the Study of Maimonides' Mishneh Torah (Cambridge, MA Harvard University Press, 1984). 
declares that to enjoy political rights and participate in the felicitous destiny of a Fifth Empire identified with the Kingdom of Christ, the Portuguese descendants of New Christians need not either join Judaism nor withdraw from the church, because, in such a kingdom, soon to be instituted by Portugal, men of all nations would be saved, including those of Jewish origin. The descendants of New Christians were thus assured by Vieira that they had no need to seek shelter in Judaism in order to enjoy full political and religious rights, because they would obtain those rights in the broader sense of Christianity he was proposing. Like ben Israel, Vieira was vying for merchants and men of letters, many of whom were rich, noble, and honorable, and who had been expelled from Portugal due to the intolerance of the Holy Office. By the 166os, however, Vieira's writings were condemned by the Inquisition, the sons and successors of King John IV had lost interest in Vieira's prophecies and proposals to attract New Christians' descendants to Christianity, and the latter, who had since become "New Jews," had no reason to return to Portugal. 